\title{
計量心理学的解析手法による商業・業務系建築物前面の景観評価に関する研究
}

\section{A Psychometric Study on City-scapes Composed of Commercial or Office Building Facades and Front Spaces}

\author{
山口 徹* 屋代雅充** \\ Tohru YAMAGUCHI Masamichi YASHIRO
}

\begin{abstract}
摘要 : 商業系と業務系の建築物ファサードおよび前面空間は都市景観を構成する重要な要素と考えら れる。そこで、これらの要秦の中の何が景観評価を左右しているかを客観的に明らかにするために， 合成写真を含むスライド映写画像による被験者評価実験を行った。実験では，予備実験により絞り込 んだ複数の評価項目を用意した。そして評価項目ごとに被験者回答の傾向を分析し、次いで評価平均 值について，重回帰分析と数量化理論 I 類分析を適用し，景観を構成する建築部位である，緑や花， 開口部、壁面，看板、放置物が各評価項目に特に影響を与えていることを明らかにした。
\end{abstract}

1.はじめに

近年, 都市景観に対する社会的関心が高まっており, 都市景観 を構成する重要な要素である建築物に主体的な配慮が求められる ようになってきている。また，全国各都市で景観に関する条例や 指導要綱が施行される例が多くなっており，建築物各々について 都市景観上の観点から社会的要請が強まっていく傾向にある。そ のため, 建築計画において, 建築物の景観評価が今後重要な検討 項目になっていくものと予想される。

景観の計画設計においては，地域レベル・地区レベル・地点レ ベルでそれぞれ検討評価すべき内容が異なり"，一般に景観形成 に際しては周辺環境との相互関係を重視したトータルな発想で個々 の要素をデザインすることが重要であると考えられている。これ までの都市景観を対象とした多くの研究は, 街並みや街路といっ た面的・線的な空間内の施設群の景観評価を扱ったものがほとん どであり，地域あるいは地区レベルでの検討として位置付けられ る。これらの研究から得られる結論の多くは, 面的・線的な景観 整備方針に対して示唆を与えるものではあるが，既に熟成の進ん でしまった中心市街地にそうした結論を適用するには現実的に見 ていささか無理があることも少なくない。そこで, 本研究では地 域・地区レベルからの発想を重視しつつも, 個別的な操作の自由 度の高い地点レベルに着目し, 個々の建築物とその前面空間の実 用的なデザインの方向性を探ることとした。

これまでの街路景観評価に関する研究として, 奥谷 $(1991)^{2)}$ 船越ら $(1987)^{37}$ による研究があげられる。前者は, 中心市街地の 街路空間の物理的構成要素と通行者の心理的満足度との関連を計 量心理学的手法で解明すると共に, その結果を街路空間の景観設 計に応用できるようにしたものであり，後者は，街路空間の構成 要素と，その空間から惹き起こされる心理的状況を対照させ，そ の相関関係を明らかにしたものである。これらの研究では, 街路 空間を構成している要素を大まかに分類して分析しているため, 街路に接した建物を具体的に計画設計する上では，十分とは言え ない。また, 小柳ら $(1993)^{4)}$ による研究は, 屋外広告物の色彩, 設置形態，業種や管理主体に着目し，これらの分類に応じた屋外 広告物の除去を行った C G 用いてその効果を分析しており，興 味深い研究であるが, 対象としている要素が広告物であり，やは り全般的な建物の景観設計には適していない。

そこで本研究では, 我々が接する機会の多い中心市街地の商業
系，業務系建築物の前面(ファサード)および前面空間からなる景 観を対象とし，その景観を構成している要素のあり方とそれが歩 行者に対して与えている心理的影響の定量的関係性を計量心理学 的解析手法で明らかにすることを目的とした。これにより，建築 計画・設計において設計者が経験的あるいは主観的に判断してい たものを，客観的に明らかにしようとするものである。

\section{2. 研究の方法}

前章で述べた目的を達成するため，スライド大画面映写による 多人数景観評価実験を行った。実験に先立って，東京を中心とし た商業系・業務系の建築物ファサードおよび前面空間からなる地 点景観の構成要素を多種多様な事例から求めるため, また，実験 試料とするため, 実例観察とカラー写真撮影を約 300 筒所（約 1,200 シーン) で行った。次いで，既往の類似研究 ${ }^{1 /-5)}$ および実例 の観察, 無作為に抽出した日本国土開発の社員数名を被験者とし た予備実験を通じて印象の評価項目を設定するとともに，景観構 成要素から, 量的要因 (緑視量・花の量 - 各部位の見えの面積 高さ・セットバック量, 等) と質的要因 (植栽構成・色彩・テク スチュア・形状・手入れのよさ，等）を抽出し，評価項目との因 果関係を仮説として設定した。また，予備実験の結果および仮説 の内容から不足していると考えられるシーンを追加するため, 実 験にあたっては事例写真の追加撮影を行なうとともに，モンター ジュ写真（合成写真）を作成し，意図的に操作した評価要因を実 験試料の中に含めるようにした。実験は回答に際しての被験者の 負担を考慮し，量的要因と質的要因が明確に表出されている商業 系 86 シーン, 業務系 94 シーンの計 180 シーンに絞って行い, そ の評価実験結果を被験者の属性別に検定し, 評価平均值に関して, 重回帰分析・数量化理論第 I 類分析などを用いて計量心理学的 解析を行ない, 仮説の検証を試みた。

\section{3. 実験の概要}

被験者評価実験は, 1993 年 2 月に計 6 回（1 回に 11 15 名), 都内近郊より公募した 78 名を被験者として行った。被験者を属 性別にみると, 男 39 名・女 39 名, 一般（主婦を含む） 13 名・ 学生 65 名である。実験に先立って記入させた調査票のフェイス シートによると, 都市景観に対する関心度合いは，「深く関心あ り」・「やや関心あり」がそれぞれ全被験者の $51 \% \cdot 46 \%$ （計

*日本国土開発株式会社 技術本部 **株式会社ラック計画研究所 
97\%) を占めている。

\section{(1) 実験提示写真の撮影方法}

写真撮影の方法は，現地を再現できるようにするために，比較 的広い画角（水平画角約 $65^{\circ}$ ）の得られる焦点距離 $28 \mathrm{~mm}$ のレン ズ ( $35 \mathrm{~mm}$ 判フィルム) を使用した。撮影に際しては日当りのよ い場所を選び，建物前面の歩道上（あるいは道路上）約 $1.6 \mathrm{~m} の$ 高さから水平にレンズを向けて, 建物間口が水平画角いっぱいに 入るように複数地点から撮影した。この時の視線入射角（レンズ の光軸と建物壁面とのなす角）は概ね 30 度から 90 度であった。 また，撮影シーンの中にはできる限り歩行者が入り込まないよう に配慮した (写真一 1$)$ 。

\section{( 2 ) 評価項目と評定尺度}

予備実験を通じて評価項目（目的変数）は，商業系と業務系と では両者の評価の観点が異なり，それぞれ別々に比較評価すべき であると考えたため一部異なっている。その結果，表一 1 に示す とおりの言語対により，商業系 6 評価項目，業務系 5 評価項目を 設定した。なお，予備実験においては，これらの他に『誘引力 (入ってみたくなる)』『景観の良否』『デザインの洗練度』『入り やすさ』も評価項目として検討したが，他の評価項目との概念の 類似性および被験者にとっての判断のしやすさ等を考慮して表一 1 の評価項目に絞り込んだ。

『建物の軽重感」は「重厚さ」「压迫感」「軽快さ」「軽薄さ」 などを反映する評価概念であり，『人目の引きやすさ』は，商業 建築のオーナーあるいはテナントにとって重要な関心事であるた め, 評価にあたっては，良否の評価は含めないものとして採用し た。『品性』は，商業建築の中には建築のデザインや色彩あるい は商品のディスプレイなどで奇をてらったものや，けばけばしい ものなど，都市景観として見苦しいと思われるものもあるために 取り上げた。また『うるおい感』を業務系で採用したのは，業務 系建築物は緑の多いものから全くないものまで多様であり, 評価 の違いが表れると思われたためである。好ましさ』は,建物のデ ザインそのものの評価も含む，総体的な評価項目として採用した。

なお，評価に際しては，図－1に示す 7 段階評定尺度を使い, 各段階の中間目盛を設けて実質上 13 段階の評価ができるように した。尺度目盛には言葉による表示とその等間隔性を示すための 数值（－3３）を表示した。なお，後に述べる結果の分析に際 してはー3〜3の評定尺度值を 0 12 の尺度值に変換し，モデ ル式の数值の感度を見かけ上高めて比較しやすくした。

\section{(3) 実倹手順}

実験に使用する写真は，35mm 判のスライドにし，計 6 回の実 験とも業務系・商業系の順に提示して, 各シーンに対して各々の 評価項目について評価させた。スライドの映写方法は, 図一 2 に 示すとおりであり,縦 $1,820 \mathrm{~mm} \times$ 横 $2,730 \mathrm{~mm}$ の大画面映写で, 現地 での視角をできるだけ再現できるように被験者の座席を配置した。

各実験を開始する前に，実験の趣旨，評価項目の意味と評価の 仕方を説明し，本番に現れるシーンと同様な 5 シーンを参考提示 し評価の記入練習をさせ，実験への被験者の慣れを促した。評価 対象スライドの提示時間は 1 シーン当たり約 10 秒を与え, 評価 は深く考え込まずに直感的に判断するように指示した。なお，提 示スライドの順序は, 各回ともそれぞれランダムにして, 映写順 序によるシーン評価への影響を全体として相殺できるようにした。

\section{4. 実験の結果}

\section{（1）被験者の属性による評価の差}

被験者の属性として, 性別・年齢・専門（専攻）・座席位置に 着目し，それぞれの属性の違いが評価平均值に対して，統計的に 有意な差をもたらしているのか否かに関して，検定を行った。

年齢 (20 歳代 $\Leftrightarrow 30$ 歳以上), 専門 (専門 $\Leftrightarrow$ 非専門)，商業系に

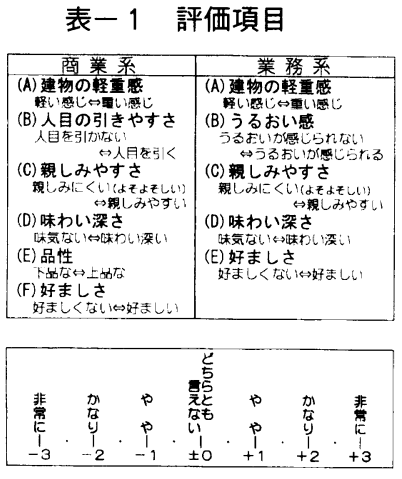

図一 17 段階評定尺度
(結果の分析に祭しては， $-3 \sim 3 の$ 評定 尺度值を0〜120尺度に変換して用いた。

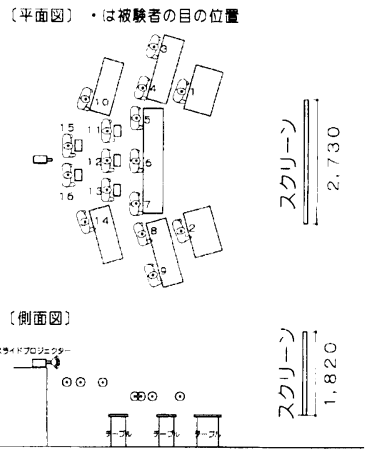

$5.300 \mathrm{~mm}$

図一２ スライドの提示方法
おける性別（男·女）の順で有意差が見られるシーンが多くなり， 最大で全体シーン数の $25 \%$ に有意差が認められた。これは，男 性向きと女性向きのデザインが存在し, 商業系での設計の際には 客層を想定したデザインが必要であることを示している。

しかし，75\%以上のシーンに関して有意差が認められていない ため, 今回は全員の評価の平均值を用いて以降の分析を進めるこ ととした。

\section{( 2 ) 実験結果の統計数理的分析 \\ (i ) 量的分析}

(1) 量的要因と評価平均値との相関関係

実験提示写真に映し込まれた量的要因として 29 個を検討し， (表一2)これらと評価平均值との相関係数を算出した。相関倸 数が著しく高いものは見当たらないが, 相関係数の絶対值が 0.5 以上となったものは，以下のとおりである。

【商業系】『品性』と「(25)看板異物類」の $\mathrm{r}=-0.717$, 『好ま しさ』と「(25)看板異物類」の $\mathrm{r}=-0.539$

【業務系】『建物の軽重感」と「(24)空全部」の $\mathrm{r}=-0.511$, 『建物の軽重感」と「(29)全壁面」の $\mathrm{r}=0.501$, 『うるおい感」 と「(1)緑」の $\mathrm{r}=0.593$,『うるおい感』と「(6)緑+空内緑 (全 緑 $) 」 の r=0.609$, 『うるおい感』と「(9)緑+花」の $r=0.619$, 『うる扔い感」と「(11)緑+花十空内緑 $($ 全緑十花 $) 」 の r=0.634$ 。 しかし，これら以外に相関係数 0.5 以上のものは見当たらず, 各評価と量的要因とが単純な直線的関係では捉えきれない複雑な 構造を有しているものと推察される。

(2) 重回㷌分析

\section{表 -2 量的要因（説明変数）}

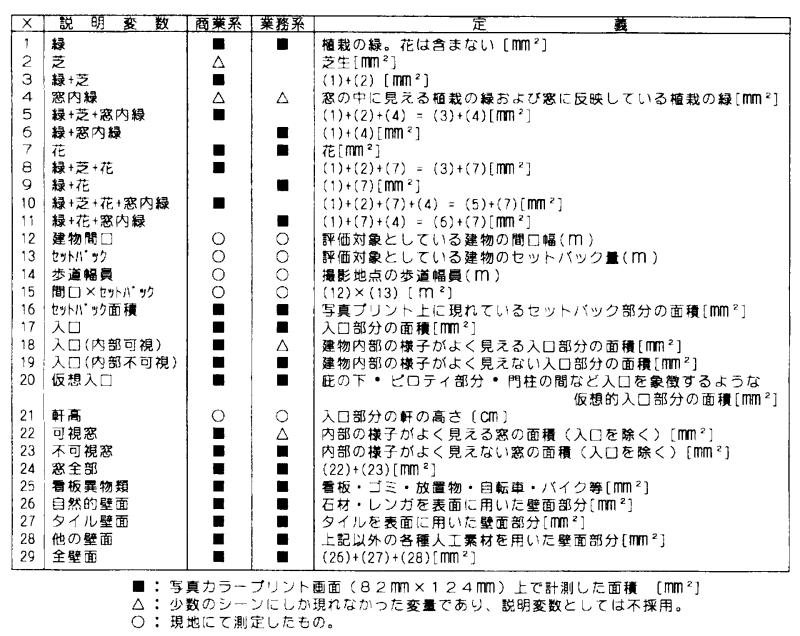


量的要因を説明変数とし，評価平均值を目的変数として，重回 㷌分析を行った。

重回帰分析にあたっては，上記の結果である相関係数の絶対値 が 0.05 未満のものは説明変数として採用しないものとし，また 説明変数の内部相関の絶対值が 0.5 以上のものについては, それ らの説明変数のうちで目的変数との相関係数が最も高い方を採用 することとした。次いで, 偏相関係数の絶対值が低い説明変数か ら順に削除しながら重回㷌分析を繰り返し、【商業系】【業務系 】で計 11 の重回帰分析モデルを得た。 $\mathrm{t}$ 検定の結果, 採用した 説明変数はすべて統計的に有意である (表一 3 )。これらの中で 比較的決定係数が大きいものを考察すると次のようになる。

【商業系】については, 『品性』は,「入口（内部可視）」「看板 異物類」「他の壁面」ともにマイナスに効き， $\mathrm{Y}=8.0805-0.000$ $4 \mathrm{X}_{18}-0.0008 \mathrm{X}_{25}-0.0003 \mathrm{X}_{28}$ の重回帰モデルが得られた。なお決 定係数は 0.628 である。また「看板異物類」が多いほど，「下品」 方向への影響を一番有している。『好ましさ』は,「緑十芝+花十 空内緑」がプラスに効き「看板異物類」「他の壁面」がマイナスに
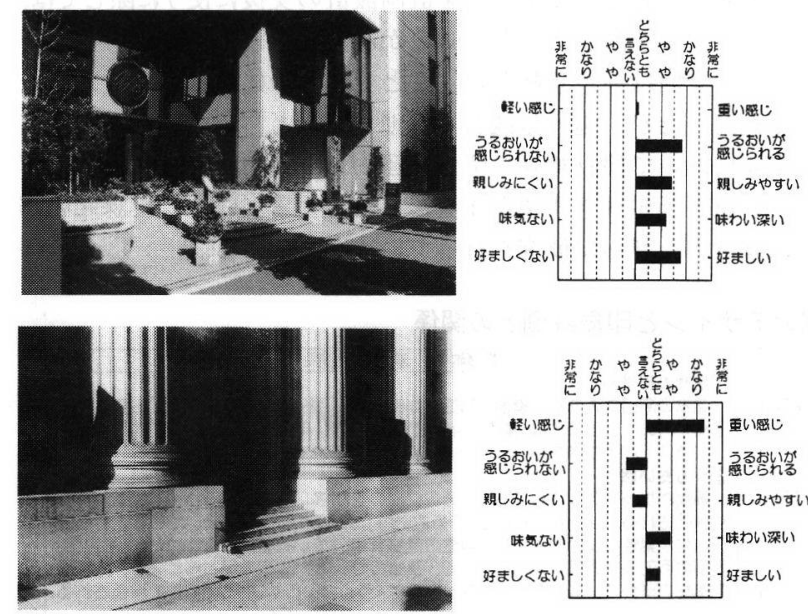

写真一 1 代表的なシーンとその評価平均值

\section{表一 3 重回帰分析モデル表}

\begin{tabular}{|c|c|c|c|c|c|c|}
\hline & 目的变数 $(Y)$ & 説 明 変 数 " & 偏回帰係数 & 偏相関係数 & $\begin{array}{l}\text { 標準偏 } \\
\text { 回 㫶係数 }\end{array}$ & 定 数 \\
\hline \multirow{10}{*}{ 商 } & 建物の㣮重感 & 緑 & -0.0004 & -0.396 & -0.3529 & \multirow{6}{*}{7.3631} \\
\hline & $r=0.643$ & 歩道幅貝 & 0.2747 & 0.394 & 0.3372 & \\
\hline & & 入口(内部可視) & -0.0005 & -0.351 & -0.3128 & \\
\hline & & 㤎全部 & -0.0003 & -0.267 & -0.2147 & \\
\hline & & 着板翼物類 & -0.0004 & -0.423 & -0.3754 & \\
\hline & & 他の壁面 & -0.0004 & -0.432 & -0.3712 & \\
\hline & 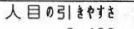 & 歩道幅員 & 0.1935 & 0.242 & 0.2282 & \multirow[t]{3}{*}{8.5918} \\
\hline & $r=0.422$ & $\ln$ (密全部) & -0.2286 & -0.316 & -0.3084 & \\
\hline & $r^{2}=0.178$ & $\ln$ (箐板異物類) & -0.1047 & -0.241 & -0.2254 & \\
\hline & 漞しみやすさ & 緑 +芝 & 0.0003 & 0.327 & 0.3200 & \multirow[t]{3}{*}{5.8968} \\
\hline \multirow[t]{4}{*}{ 業 } & $r=0.432$ & 花 & 0.0019 & 0.218 & 0.1986 & \\
\hline & $r^{2}=0.187$ & 入口(内部可視) & 0.0006 & 0.387 & 0.3864 & \\
\hline & 味わい深さ & 緑 + 芝 + 花 & 0.0003 & 0.300 & 0.2586 & \multirow[t]{3}{*}{6.0899} \\
\hline & $r=0.590$ & 看板異物㓋 & -0.0004 & -0.425 & -0.3857 & \\
\hline \multirow[t]{11}{*}{ 采 } & $r^{2}=0.349$ & 自然的壁面 & 0.0003 & 0.376 & 0.3324 & \\
\hline & \multirow{3}{*}{$\begin{array}{l}r=0.792 \\
r^{2}=0.628\end{array}$} & 入口(内部可視) & -0.0004 & -0.301 & -0.2014 & \multirow[t]{3}{*}{8.0805} \\
\hline & & 看板異物類 & -0.0008 & -0.720 & -0.6631 & \\
\hline & & 他の壁面 & -0.0003 & -0.440 & -0.2943 & \\
\hline & 好ましさ & 緑 +芝 +花 +勰内緑 & 0.0003 & 0.306 & 0.2559 & \multirow[t]{3}{*}{7.1684} \\
\hline & $r=0.644$ & 看板異物類 & 0.0006 & -0.547 & -0.5025 & \\
\hline & $r^{2}=0.415$ & 他の壁面 & -0.0002 & -0.276 & -0.2252 & \\
\hline & 建物の柽重感 & 建物間口 & 0.0348 & 0.277 & 0.2185 & 6.9385 \\
\hline & $r=0.659$ & セットパック & -0.1595 & -0.324 & -0.2629 & \\
\hline & $r^{2}=0.435$ & 密全部 & -0.0007 & -0.468 & -0.4021 & \\
\hline & & 自然的壁面 & 0.0002 & 0.366 & 0.2988 & \\
\hline \multirow[t]{4}{*}{ 業 } & らるおい感 & 緑＋空内粶 & 0.0011 & 0.557 & 0.6108 & \multirow[t]{3}{*}{5.7948} \\
\hline & $r=0.710$ & 花 & 0.0078 & 0.447 & 0.3469 & \\
\hline & $r^{2}=0.504$ & 全壁面 & -0.0002 & -0.228 & -0.1538 & \\
\hline & 視しみやすさ & 緑 & 0.0007 & 0.450 & 0.4124 & \multirow[t]{3}{*}{5.0304} \\
\hline \multirow[t]{4}{*}{ 務 } & $r=0.570$ & 花 & 0.0067 & 0.393 & 0.3466 & \\
\hline & $r^{2}=0.325$ & 壳全部 & 0.0005 & 0.396 & 0.3529 & \\
\hline & 味わい深さ & 緑＋花＋恕内緑 & 0.0007 & 0.489 & 0.4344 & \multirow{3}{*}{4.3973} \\
\hline & $r=0.656$ & 軒高 & 0.0021 & 0.349 & 0.2901 & \\
\hline \multirow[t]{5}{*}{ 系 } & $r^{2}=0.430$ & 自然的壁面 & 0.0003 & 0.470 & 0.4046 & \\
\hline & \multirow{4}{*}{$\begin{array}{l}\text { 好ましさ } \\
r=0.653 \\
r^{2}=0.426\end{array}$} & 緑＋㤎内緑 & 0.0008 & 0.545 & 0.5067 & \multirow{4}{*}{4.9672} \\
\hline & & 花 & 0.0044 & 0.271 & 0.2198 & \\
\hline & & 軒高 & 0.0015 & 0.253 & 0.2151 & \\
\hline & & 自然的壁面 & 0.0002 & 0.362 & 0.2949 & \\
\hline
\end{tabular}

効いている。その重回帰モデルは, $\mathrm{Y}=7.1684+0.0003 \mathrm{X}_{10}-0.00$ $06 \mathrm{X}_{25}-0.0002 \mathrm{X}_{28}$ で, 決定係数は 0.415 である。「看板異物類」が 多いほど,「好ましくない」方向へ効き, 逆に「緑」や「花」が多い ほど「好ましい」方向に効く。

一方，【業務系】においては, 『建物の軽重感』は,「建物間口」 「自然的壁面」がプラスに効き,「セットバック量」「空全部」が マイナスに効き, $\mathrm{Y}=6.9385+0.0348 \mathrm{X}_{12}-0.1595 \mathrm{X}_{13}-0.0007 \mathrm{X}_{24}$ $+0.0002 \mathrm{X}_{26}$ の重回帰モデルが得られた。なお決定係数は 0.435 である。「空の量」が多いほど「軽い」方向への効果を有し,「自然 的壁面」が多いと「重い」方向への効果を有している。『うるお い感」は,「緑十空内緑」「花」がプラスに効き,「全壁面」がマ イナスに効いている。その重回帰モデルは, $\mathrm{Y}=5.7948+0.0011$ $\mathrm{X}_{6}+0.0078 \mathrm{X}_{7}-0.0002 \mathrm{X}_{29}$ で, 決定係数は 0.504 である。『味わ い深さ』は,「緑十花+窓内緑」「自然的壁面」「軒高」の順でプ ラスに効き, $\mathrm{Y}=4.3973+0.0007 \mathrm{X}_{5}+0.0021 \mathrm{X}_{21}+0.0003 \mathrm{X}_{26}$ の重 回帰モデルが得られた。なお決定係数は 0.430 である。「軒高」 が「味わい深い」方向に効いているが,「軒高」が高い建物は概 して高品質な素材を用い, 手の込んだ造りになっていることが多 いからだと思われる。『好ましさ』は,「緑十空内緑」「自然的壁 面」「花」「軒高」の順でプラスに効き， $\mathrm{Y}=4.9672+0.0008 \mathrm{X}_{6}$ $+0.0044 \mathrm{X}_{7}+0.0015 \mathrm{X}_{21}+0.0002 \mathrm{X}_{26}$ の重回㷌モデルが得られ, 植 栽の重要性が認められる。なお決定係数は 0.426 である。

(ii) 質的分析

実験提示写真に映し込まれた質的要因は, 表一 4 に示すような アイテムに整理された。

そして, これらを説明変数とし, 評価平均值を外的基準として 数量化理論 I 類による分析を行い, カテゴリースコア・偏相関 係数・レンジを計算した。ここで, 数量化理論 I 類による分析 では, カテゴリー数は, サンプル (評価シーン) 数よりも十分に 少ない方が好ましいため, サンプル数の約 $1 / 3$ を目安として, カテゴリー数を商業系で 28 以下, 業務系で 31 以下となるように, 評価平均值と説明変数の相関倸数が低いものを順に削除し,アイ テムを絞り込んでいった。さらにモデルの構造を単純化し，より 少ない要因で現象を説明できるように, 偏相関係数が低い比較的 効きの弱いアイテムを順番に除去していって, 決定倸数が極端に 低下する直前のモデルを採用することとした。その結果, 比較的 決定係数が大きいものをまとめて表一 5 に示す。

【商業系】の, 『品性』については,「看板・サインの統合」 「壁面の素材」「植栽樹木の構成」「シーン中の色数」の順で影響を 示しており，「看板サインが統合されていない」と下品な印象を 与えている。「好ましさ』は,「看板・サインの統合」「植栽樹木の 構成」「壁面の素材」「シーン中の色数」の順で影響を示しており， 「看板サインが統合されていない」と好ましくない印象を与える。

一方【業務系】の,『うるおい感』には,「植栽樹木の構成」 「壁面の素材」「ひさし・日除の有無」の順で影響があり, 特に 「植栽樹木の構成」の影響力は他のアイテムにくらべて大きく, 樹種が多いほど『うるおい感』を高める。また,「パネル」の壁面 はうるおいを減じさせることが知れる。『味わい深さ」は「緑視 量」「壁面の素材」「装飾品の有無」「看板・サインの統合」「建物 の手造り感」の順で影響があり, 緑がシーンの中に占める割合が

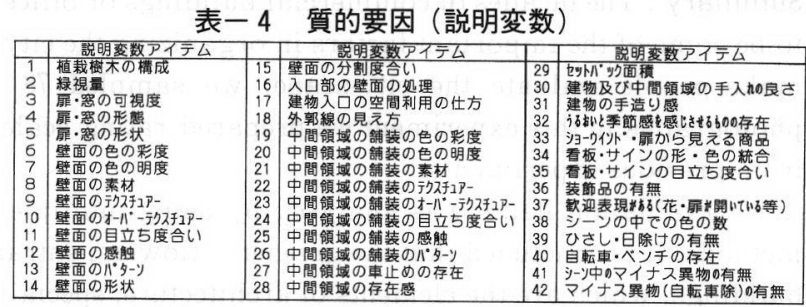


表一 5 数量化 I 類モデル

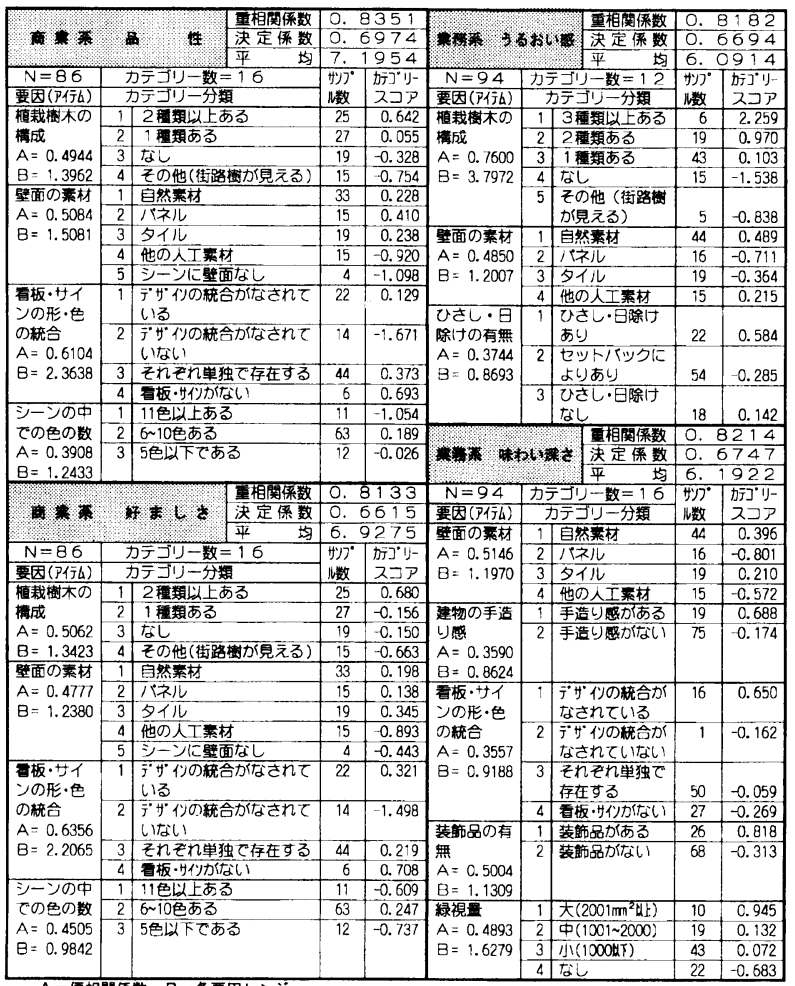

多いほど味わい深いほうへ移行することが解った。

5. まとめ

従来, 主観的・経験的になされてきた建築空間のデザインの一 側面に関して, 本研究により客観的な判断資料を提供することが できる（表一 6 )。これらの結論は，経験的にはある程度まで認 識されていたものも少なくない。しかし，建築部位のどこをどう 操作すればどのように評価が変化するのかを明確化できたという 点で，デザインの客観的な手がかりとして有効であるばかりでな く,デザインの意図を他者に伝えるための根拠としても有用と考 えられる。

\section{6.おわりに}

本研究により建物ファサードおよび前面空間の計画設計を支援 するための客観的なモデル式を抽出することができた。ただし， こうしたモデル式ですべてが説明されたわけではなく，むしろモ デル式に組み込むことのできなかった要因も少なからず残されて いると考えられる。モデル式を計画設計の支援に使うに際しては, そうした限界を踏まえておく必要がある。

また，今回は地点景観ということで個々の建築物 1 棟を対象と して検討したが，地区景観および地域景観と言う面では，より広 い空間において建物相互の関係や建物と周辺物との関係の中でデ ザインを評価すべき事項が多数残されている。こうした課題の解 決に向けて, さらに研究を行っていく所存である。

$A=$ 価相蔺保数・B=各要因レンジ

表一 6 建築ファサードおよび前面空間のデザインと印象評価との関係

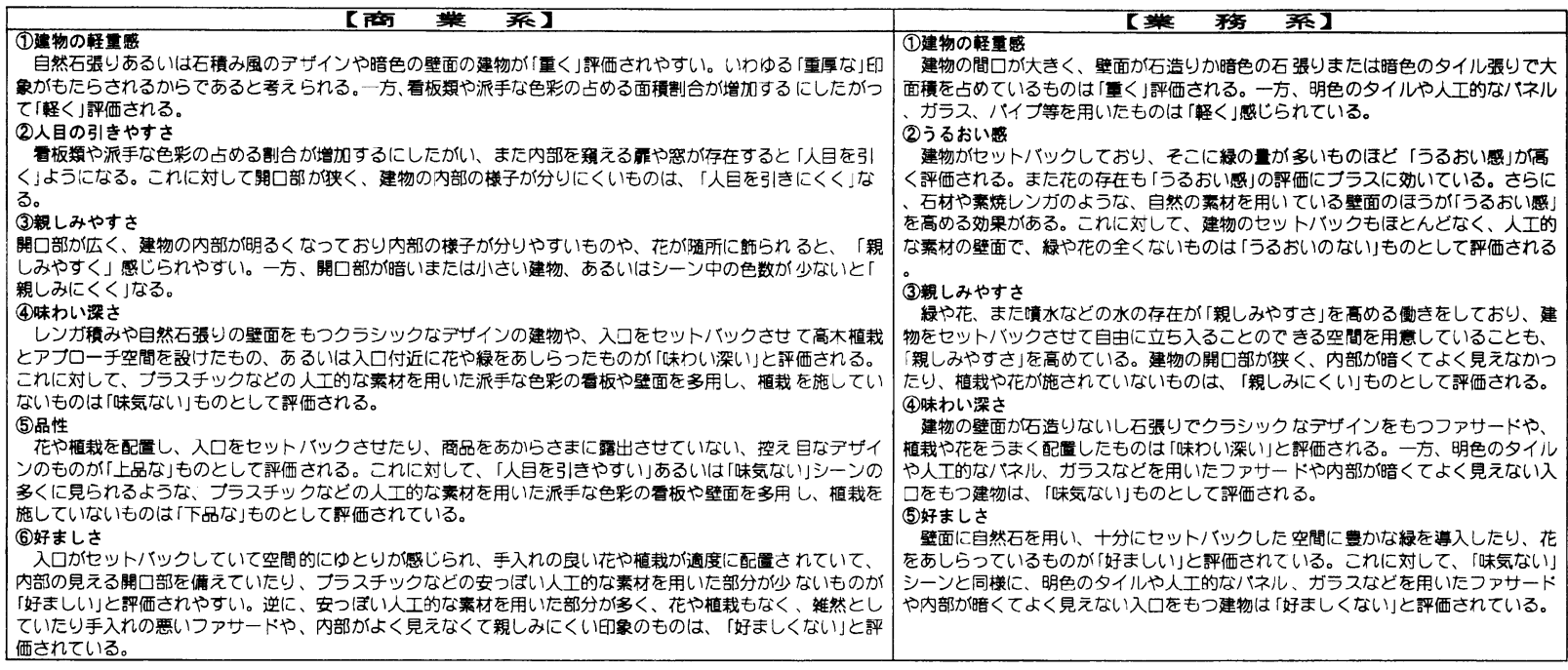

\section{参考文献}

1 ) 屋代雅充（1992）：景観計画設計手法 の体系化：造園雑誌 56(2),146-153

2 ) 奥谷 嚴 (1991): 計量心理学的手法に よる都市景観設計手法の開発 : 電気学 会論文誌 111 巻 12 号, 1057-1064

3 ）船越 徹 ·積田 洋 (1987): 街路空間
における空間意識と空間構成要素との 相関関係の分析 (相関分析) 一街路空 間の研究 (その3)-：日本建築学会 論文報告集第 378 号,49-56

4 ) 小柳武和·志摩邦雄ら（1993）: 屋外広 告物が都市景観の色彩調和・イメージ
に与える影響 : 第 28 回日本都市計画 学会学術研究論文集, $523-528$

5 ) 篠原 修·屋代雅充 (1985)：街路景 観のまとまりに及ほす沿道建物の効果 に関する計量心理学的研究 : 土木学会 論文集第 353 号 $/ \mathrm{IV}-2,131-138$

Summary: The facades of commercial buildings or office buildings, and the area in front of the buildings are considerd to be some of the important factors in organizing the city-scape. In order to make objectively clear what factors really make people evaluate the city-scape, we sampled 78 subjects by showing 180 color slides including composite photographs. In this experiment we prepared rating scales for several evaluation items, which were selected carefully from previous experiments.

Each evaluation items was analysed by using multiple regression analysis and multidimensional quantification I methods. It is concluded that the greenery, flowers, entrances, walls, signs and random objects in the front space of the buildings, which are the elements of architecture, specially effect on the evaluation of the landscape of spot. 